Reprod. Nutr. Dévelop., 1983, 23 (4), 765-773.

\title{
Bile secretion in the fistulated pig: effect of the method used for bile reinfusion
}

\author{
Catherine JUSTE, T. CORRING, Y. LE COZ (*) \\ with the technical assistance of Anne-Marie GUEUGNEAU, Georgette BRACHET, A. ROGER, \\ A. VAN HECKE
}

Laboratoire de Physiologie de la Nutrition,

$\left.{ }^{*}\right)$ Laboratoire d'Ecologie microbienne,

I.N.R.A., 78350 Jouy-en-Josas, France

Summary. The aim of this work was to investigate the effects on bile secretion of flow rate and site of reinfusion of the collected bile to the animal. Thirty-two pigs weighing $50 \pm 3 \mathrm{~kg}$ at the beginning of the experiment were fitted with a reentrant fistula in the lower common bile duct and in the upper duodenum. Bile collected from the bile duct was reinfused in four different ways (four groups of 8 animals each) : into the duodenum or the lower common bile duct at a constant flow rate using a peristaltic pump, or into the duodenum or the lower common bile duct at a rate mimicking the flow rate of the secretion using an automatic apparatus.

Reinfusing the bile into the lower common bile duct at a rate mimicking the secretion rate provided a daily bile acid production about $21 \%$ higher than the level recorded with the other three methods. This was mainly due to a higher bile acid concentration since the bile flow was only slightly affected by the treatment.

\section{Introduction.}

Research on the physiology of bile secretion in relation to the diet ingested by the conscious pig eating normally requires the measurement of total amounts of bile and of its components; it is necessary to continuously collect the bile over experimental periods of several days in order to study the variation of its total quantity and of its components with the diet. Moreover, to keep the enterohepatic circulation intact and not to modify bile secretion (Dowling et al., 1968 ; Juste and Corring, 1979), the bile has to be reinfused to the animals. Depending on the study, bile has been infused into the duodenum (Nahrwold and Grossman, 1967 ; Juste, Corring and Breant, 1979) or into the lower bile duct (Laplace and Ouaissi, 1977 ; Weis and Barth, 1978 ; Lefaivre et al., 1979) either at a constant flow rate (Laplace and Ouaissi, 1977 ; Juste, Corring and Breant, 1979) or at a rate mimicking that of the secretion (Campbell et al., 1971 ; Lefaivre et al., 1979 ; Juste, Corring and Le Coz, 1983). Reinfusion at a constant flow rate probably does not correspond to the physiological conditions of bile secretion. 
First, the composition of bile infused at a given time may be different from the composition of bile secreted at that time. Secondly, reinfusing at a constant rate does not take into account the fluctuations of bile flow, particularly after stimulation by meal consumption. Moreover, direct reinfusion of bile into the duodenum by-passes the sphincter of Oddi and neglects the putative physiological function of this muscle in the control of bile secretion (Watts and Dunphy, 1966 ; Wyatt, 1967). To the best of our knowledge, no study has been done in a same species to investigate the effects upon bile secretion of different methods of bile reinfusion to the animal.

The aim of the present experimental work was to study the effects of bile restitution flow rate (constant or mimicking the pattern of bile secretion) and the effects of the site of bile infusion (duodenum or lower common bile duct) on bile secretion in fistulated pig.

\section{Material and methods}

Animals and diet. - Thirty-two castrated Large-White pigs weighing $50 \pm 3 \mathrm{~kg}$ at the beginning of the experiment were fitted with three permanent fistulae, one in the common bile duct for the collection of bile, one in the lower common bile duct and one in the duodenum for reinfusing the secretion. After surgery, the animals were housed in individual, metabolism-type restraining cages and allowed to recover for 10 days before experimentation. This period was sufficient to stabilize bile flow and bile acid output.

For one week before surgery, the pigs were adapted to the experimental diet (2.11\% fat, $16.86 \%$ protein and $57.34 \%$ nitrogen-free extract) the composition of which has been described previously (Corring and Bourdon, 1977). Feed was provided throughout the experimental period in two equal meals of $800 \mathrm{~g}$ each (food/water : 1/2) at $9 \mathrm{a} . \mathrm{m}$. and $4 \mathrm{p} . \mathrm{m}$. The windowless animal room was artificially illuminated with lights at on 7. a.m. and off at 7. p.m. Temperature was adjusted at $20^{\circ} \mathrm{C}$ for 3 or 4 days after surgery, then lowered to $18^{\circ} \mathrm{C}$.

Surgical procedure. - We used an extension of the method described previously (Juste, Corring and Breant, 1979). Under general anaesthesia and sterile conditions, the peritoneal cavity was opened and the common bile duct was identified distally to the entry of the cystic duct at about $2 \mathrm{~cm}$ from the duodenum. After the duct wall had been incised longitudinally for $0.5 \mathrm{~cm}$, a medical silastic catheter (outer $\varnothing: 4.88 \mathrm{~mm}$, inner $\varnothing: 2.64 \mathrm{~mm}$ ) was inserted upwards and ligated into place. A second incision of $0.3 \mathrm{~cm}$ was made between the first one and the sphincter of Oddi. A silastic tube of small diameter louter $\varnothing: 3.18 \mathrm{~mm}$; inner $\varnothing: 1.57 \mathrm{~mm}$ ) was gently inserted downwards without reaching the sphincter muscle and was ligated into place. A third silastic catheter louter $\varnothing: 3.18 \mathrm{~mm}$; inner $\varnothing: 1.57 \mathrm{~mm}$ ) was inserted into the proximal duodenum, opposite to the opening of the common duct, and ligated into place. The three catheters were exteriorized through separate stab wounds in the right flank and the abdomen was closed in layers after a penicillin solution (1000000 U) had 
been poured into the abdominal cavity. After surgery, antibiotics (penicillin $1000000 \mathrm{U}$; streptomycin : $1.0 \mathrm{~g}$ ) were given daily by intramuscular injection for 3 days. The bile began to drop from the biliary fistula immediately after surgery, and was restituted according to the experimental procedure.

Experimental procedure. - The aim of this experiment was to study the effect on bile secretion of an automatic or constant rate of bile reinfusion into either the lower bile duct or the duodenum. The pigs were divided into four experimental groups. In groups A (8 pigs) and B (8 pigs), bile was reinfused into the duodenum and the lower common bile duct, respectively, using an automatic apparatus previously described in detail (Juste, Corring and Le Coz, 1983). Briefly, the collected bile was diverted through the apparatus and immediately reinfused to the animal at a rate mimicking the pattern of bile secretion. The apparatus allowed automatic measurement of the volume of bile secreted and continuous collection of a representative part of the secretion for chemical analysis. In groups $\mathrm{C}(8$ pigs) and $\mathrm{D}$ ( 8 pigs), bile was reinfused at a constant rate into the duodenum and the lower common bile duct, respectively, using a peristaltic pump. This scheme was applied over the experimental period as well as over the recovery period.

Utilization of the fistulae. - In groups A and B, a fraction of bile automatically withdrawn hourly in a fraction collector was kept in a refrigerated dark box. Twice a day the samples were stored at $-70^{\circ} \mathrm{C}$ until analysis.

In groups $C$ and $D$, the bile was totally collected in the fraction collector. In each tube, a $4 \%$ sample was kept for analysis, and the remaining bile was returned to the animal using a peristaltic pump (Juste, Corring and Breant, 1979). The rate of the pump was changed in the daytime to infuse bile at $180 \mathrm{ml} / \mathrm{hr}$ over a 3-hour period after each meal; it worked at $80 \mathrm{ml} / \mathrm{hr}$ the rest of the time (Juste, Corring and Breant, 1979). Bile collections were pooled at 9 a.m., noon and 5 p.m. prior to infusion (Juste, Corring and Breant, 1979).

Measurements of bile secretion. - After a 10-day recovery period, the animals were submitted to a 6-day experimental period during which bile secretion was measured.

The volume of bile was measured hourly in all groups of pigs. In the automatically infused groups, this volume was calculated by counting the marks on the recorder paper. In groups $C$ and $D$, it was read on the collecting tubes. Total bile acids in the samples were determined enzymatically (Talalay, 1960).

The volume of bile secretion was expressed in $\mathrm{ml}$, total bile acid concentration in $\mathrm{mmol} / \mathrm{l}$ of bile and total bile acid output in $\mathrm{mmol}$.

\section{Results}

Three pigs in group A and one in group $B$ were eliminated from the experiment because one catheter was rejected during the experimental period. The 
remaining pigs evidenced no particular health problem and food consumption was complete throughout the experiment. The mean daily weight gain was $460 \pm 40 \mathrm{~g}$ with no significant difference according to treatment. All the data obtained were analyzed on a CII H.B. IRIS 80 computer, and their statistical significance was studied using multidimensional variance analysis.

The reported results first concern the measurement of bile secretion per $24 \mathrm{hrs}$, then bile secretion observed during three periods of the light/dark cycle : a 7-hour interval after the first meal, a 7-hour interval after the second meal and a 10-hour nocturnal interval.

Statistical analysis showed a significant animal effect (table 1) on the volumes, concentrations and amounts of secreted bile acids in all the time periods studied (whole light/dark cycle, first or second postprandial period, nocturnal period). We also found an interaction between the rate of restitution (constant flow or flow mimicking bile secretion) and the bile restitution site (lower bile duct or duodenum) in relation to the concentrations and amounts of secreted bile acids. This interaction effect was less for the volumes of bile secreted during the whole light/dark cycle and non-existent for each of the three intervals studied.

TABLE 1

Bile secretion in the pig. Statistical analysis of animal effect and interaction between bile restitution site and rate.

\begin{tabular}{|c|c|c|c|c|c|}
\hline & & Daily values & $\begin{array}{c}\text { 7-hour interval } \\
\text { after } \\
\text { the 1st meal }\end{array}$ & $\begin{array}{l}\text { 7-hour interval } \\
\text { after } \\
\text { the } 2 \text { nd meal }\end{array}$ & $\begin{array}{c}\text { 10-hour } \\
\text { nocturnal } \\
\text { interval }\end{array}$ \\
\hline $\begin{array}{l}\text { Bile acid } \\
\text { output }\end{array}$ & $\begin{array}{l}\text { Animal effect } \\
\text { Interaction effect }\end{array}$ & $\begin{array}{l}P<0.001 \\
P<0.001\end{array}$ & $\begin{array}{l}P<0.001 \\
P<0.01\end{array}$ & $\begin{array}{l}P<0.001 \\
P<0.025\end{array}$ & $\begin{array}{l}P<0.001 \\
P<0.001\end{array}$ \\
\hline $\begin{array}{l}\text { Bile } \\
\text { flow }\end{array}$ & $\begin{array}{l}\text { Animal effect } \\
\text { Interaction effect }\end{array}$ & $\begin{array}{l}\mathrm{P}<0.001 \\
\mathrm{P}<0.05\end{array}$ & $\begin{array}{l}P<0.001 \\
\text { NS * }\end{array}$ & $\begin{array}{l}P<0.001 \\
N^{*}{ }^{*}\end{array}$ & $\begin{array}{c}P<0.001 \\
\text { NS * }\end{array}$ \\
\hline $\begin{array}{c}\text { Bile acid } \\
\text { concentration }\end{array}$ & $\begin{array}{l}\text { Animal effect } \\
\text { Interaction effect }\end{array}$ & $\begin{array}{l}\mathrm{P}<0.001 \\
\mathrm{P}<0.001\end{array}$ & $\begin{array}{l}P<0.001 \\
P<0.025\end{array}$ & $\begin{array}{l}P<0.001 \\
P<0.001\end{array}$ & $\begin{array}{l}P<0.001 \\
P<0.001\end{array}$ \\
\hline
\end{tabular}

Multidimensional variance analysis on CII H.B. IRIS 80 computer.

* Non-significant.

Effect of reinfusion site (table 2). - When bile was reinfused at a rate mimicking that of bile secretion (groups $A$ and $B$ ), $15.3 \%$ more bile acids $(p<0.001)$ were secreted per 24 hrs when the bile was reinfused into the bile duct (group B). This was mainly due to an increased concentration of bile acids in the bile $(B>A:+16.3 \% ; p<0.001)$, the volumes remaining the same in the two groups. This effect related to bile reinfusion site was found again in the three periods of the light/dark cycle we studied.

When bile was reinfused at a constant rate (groups $C$ and D), the amount of bile acids secreted per 24 hrs was $7.0 \%$ higher $(p<0.025)$ in group $C$ animals whose bile was reinfused into the duodenum. This difference was due to the higher volume of bile secreted per $24 \mathrm{hrs}(+7.3 \% ; p>0.001)$ by group $C$ ani- 
Bile secretion in fistulated pig

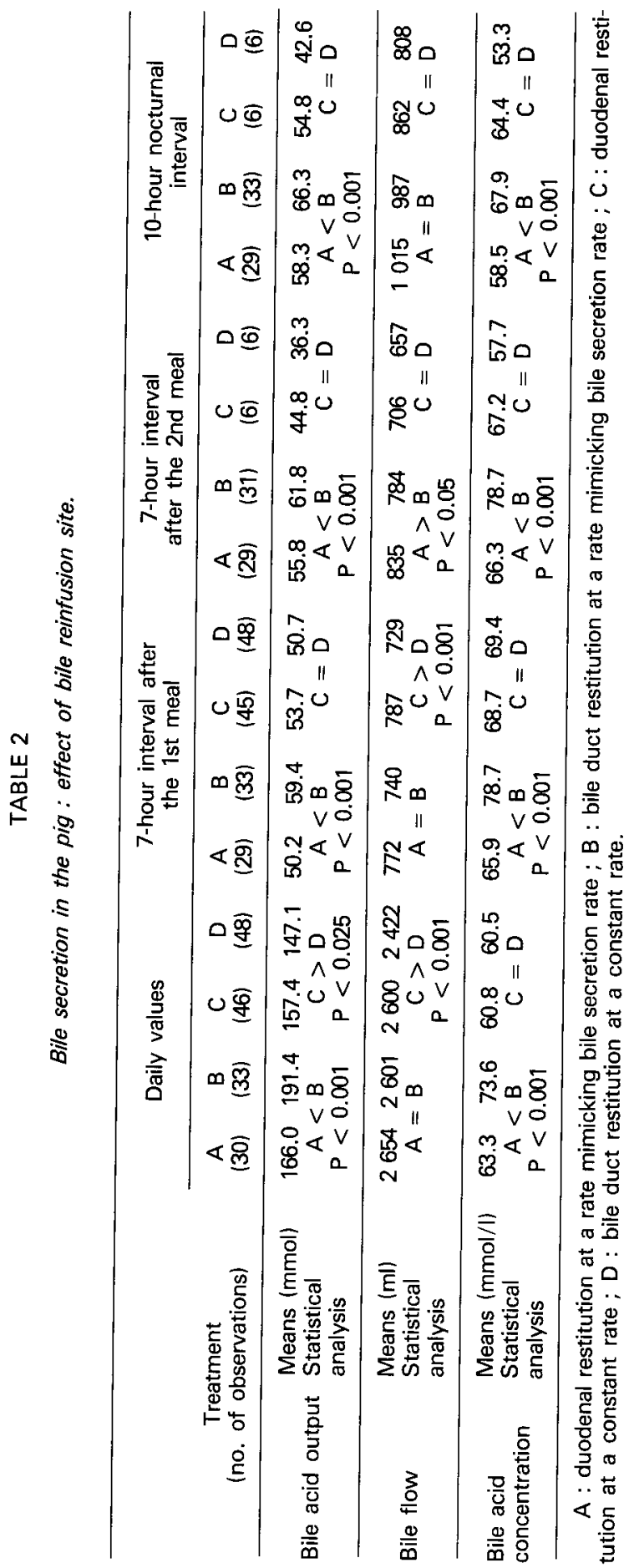


C. JUSTE et al.

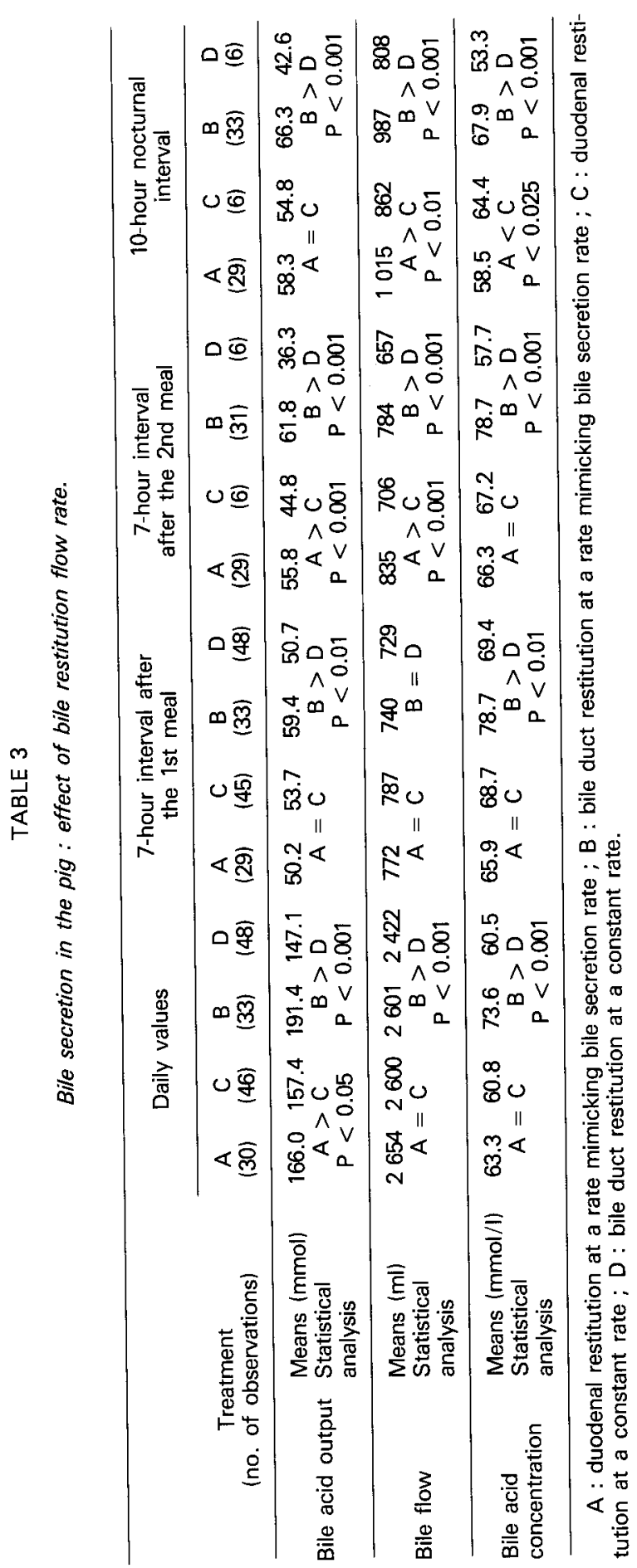


mals, the bile acid concentrations in the bile remaining the same in both groups. The increase in bile volume over $24 \mathrm{hrs}$ in each of the three periods studied during the light/dark cycle seemed to result entirely from the response of bile secretion to the first meal.

Effect of bile reinfusion rate (table 3 ). - When the rate of bile reinfused into the lower bile duct (groups B and D) mimicked the rate of bile secretion, the amount of bile acids secreted per 24 hrs was more than $30 \%$ higher $(p<0.001)$ in group $B$ animals. This was owing to an increase in the volume of bile secreted per $24 \mathrm{hrs}(+7.4 \% ; p<0.001)$, but mainly to an increase in the concentration of bile acids in the bile $(+21.7 \% ; p<0.001)$. This effect related to bile infusion rate was found again in the three periods studied in the light/dark cycle, except for the first postprandial period in which the volumes were the same whatever mode of reinfusion was used.

When bile was reinfused into the duodenum (groups $A$ and $C$ ), group $A$ showed a slightly higher amount of secreted bile acids over the 24-hr period $(+5.5 \% ; p<0.05)$. This difference was due entirely to the response of bile secretion to the second meal $(+24.6 \% ; p<0.001)$.

\section{Discussion.}

In the present study, statistical analysis shows that bile acid secretion measured over $24 \mathrm{hrs}$ depended on the animal, the site and the rate of bile restitution, and lastly that there was an interaction between the bile restitution site and the rate. Because of this interaction, the effect of the reinfusion site differed according to the rate of bile reinfusion to the animal. This effect was slight when the bile was reinfused at a constant rate, but it was considerable when the bile was reinfused at a rate mimicking the bile secretion rate : the quantity of total bile acids secreted per 24 hrs was $15.3 \%$ higher when the bile was infused into the bile duct.

Also, the effect of bile restitution rate differed, depending on whether the bile was reinfused into the duodenum or into the lower bile duct. This effect was slight when the bile was infused into the duodenum, while it was very marked when the bile was infused into the lower bile duct : the quantity of total bile acids secreted per $24 \mathrm{hrs}$ was $30.1 \%$ higher with the automatic apparatus.

We conclude from all these observations that the reinfusion of bile into the lower bile duct at a rate mimicking the pattern of secretion led to a marked rise in daily bile acid secretion. The mean bile acid output in that case was about $21 \%$ higher than the output recorded when the bile was automatically infused into the duodenum or at a constant rate into either the lower duct or the duodenum. We could not determine from these results which of the treatments should be used to measure true bile flow or the true amount of bile acids circulating every day in the intact animal. In this connection, the daily amount of bile acids passing through the enterohepatic circulation of the rat, when the bile was selfreturned into the common bile duct (Weis and Barth, 1978), was about $60 \%$ 
higher than the values reported by earlier investigators. The latter authors used other techniques such as estimations of the bile acid flux, based on the measurement of bile acid pool size and the number of circulations (Van Belle, 1965) or derived from the infused amount of bile salts required to keep bile salt synthesis in an inhibited state (Shefer et al., 1969).

The reported daily means in the pig emphasize that the higher daily bile acid output (recorded when bile was automatically infused into the lower common bile duct) was mainly due to higher bile acid concentration since the bile flow was only slightly affected by the treatment. What mechanism could have induced a higher bile acid concentration in the pig when the lower common bile duct was infused automatically? No assumption can be supported by the data obtained in the present study. Nevertheless, the involvement of the gallbladder, which in the pig can truly concentrate the bile acids in bile (Egger et al., 1974), has to be ruled out for it has been shown to empty according to the same kinetics, whatever the site of bile infusion (duodenum or lower bile duct) when the automatic apparatus is used (Jimenez, Juste and Corring, 1983). Moreover, the gallbladder of the pig empties within the first hour after meal consumption (Laplace, 1976: Jimenez, Juste and Corring, 1983), whereas the results presented here show that whatever period was studied (first or second postprandial or nocturnal), bile acid concentration was about 16 to $23.5 \%$ higher when the bile was automatically reinfused into the lower bile duct than when it was infused by any other means. We suggest that another step of the enterohepatic circulation must have been implicated. Did increased bile salt secretion result from increased bile salt synthesis, a larger bile salt pool, or from more rapid enterohepatic cycling ? Our study cannot answer these questions.

In conclusion, the results obtained in this study illustrate the importance of the methods used. They show that reinfusing the bile into the lower common bile duct of the pig at a rate mimicking that of its secretion leads mainly to a significantly higher daily output of bile acids than that recorded when the bile is reinfused at the same rate into the duodenum or at a constant rate into either the lower common bile duct or the duodenum. It would be of great interest to know if one, and if so, which one, of the porcine bile secretion levels described in this study reflects physiological secretion in the intact animal.

Reçu en décembre 1982. Accepté en mars 1983.

Acknowledgements. - We wish to thank Mr. J. P. Ley for his valuable advice on the statistical interpretation of our data.

Résumé. Sécrétion biliaire chez le porc fistulé : effet de la méthode de restitution de la bile à l'animal.

Le présent travail a pour but de mesurer la sécrétion de bile et d'acides biliaires chez le porc fistulé et réintroduit selon 4 techniques différentes. 32 porcs de race Large White et de poids vif moyen $50 \pm 3 \mathrm{~kg}$ en début d'expérience sont équipés d'une fistule biliaire, 
réentrante dans le duodénum proximal et dans le bas-cholédoque. La bile collectée à partir du canal cholédoque est retournée à l'animal selon 4 méthodes ( 4 groupes de 8 animaux) : dans le duodénum ou dans le bas-cholédoque à débit constant à l'aide d'une pompe péristaltique; dans le duodénum ou dans le bas-cholédoque selon un débit instantanément réglé sur le débit de sécrétion à l'aide d'un appareil automatique mis au point au laboratoire. La réintroduction de bile dans le bas-cholédoque selon un débit calqué sur celui de la sécrétion conduit à observer un niveau de sécrétion d'acides biliaires supérieur de $21 \%$ environ au niveau enregistré en réponse aux 3 autres traitements. Ceci est dû essentiellement à de fortes concentrations d'acides biliaires observables tout au long du nycthémère, alors que le débit de bile est peu affecté par le traitement.

\section{References}

CAMPBELL C. B., BURGESS P., ROBERTS S. A., DOWLING R. H., 1971. The use of rhesus monkeys to study biliary secretion with an intact enterohepatic circulation. Aust. N.Z.J. Med., 1, 49-56.

CORRING T., BOURDON D., 1977. Exclusion of pancreatic exocrine secretion from intestine in the pig. Existence of a digestive compensation. J. Nutr., 107, 1216-1221.

DOWLING R. H., MACK E., PICOTT J., BERGER J., SMALL D. M., 1968. Experimental model for the study of the enterohepatic circulation of bile in rhesus monkeys. J. Lab. clin. Med., 72, 169-176.

EgGeR G., KUTZ K., STREBel H., BICHER J., WEBER H., SCHOLL E., PREISIG R., 1974. Bile formation in the intact pig. Am. J. vet. Res., 35, 1203-1208.

JIMENEZ R., JUSTE C., CORRING T., 1983. By-passing the sphincter of Oddi does not affect gallbladder emptying in the pig. Reprod. Nutr. Dévelop., 23, (in press).

JUSTE C., CORRING T., 1979. Effet d'une interruption et de restitutions partielles du recyclage entéro-hépatique sur le niveau de l'excrétion biliaire chez le porc. Ann. Biol. anim. Bioch. Biophys., 19, 405-412.

JUSTE C., CORRING T., BREANT Ph., 1979. Excrétion biliaire chez le porc : niveau et réponse au repas. Ann. Biol. anim. Bioch. Biophys., 19, 79-90.

JUSTE C., CORRING T., LE COZ Y., 1983. Bile restitution procedures for studying bile secretion in the fistulated pig. Lab. anim. Sci, 33, 199-202.

LAPLACE J. P., 1976. L'excrétion biliaire chez le porc. 2. Electromyographie et dynamique de l'excrétion de bile. Rec. Méd. vét., 152, 401-411.

LAPLACE J. P., OUAISSI M. A., 1977. L'excrétion biliaire chez le porc. Influence des repas et rôle éventuel de récepteurs oddiens dans le contrôle du débit cholédocien. Ann. Zootech., 26, 595-613.

LEFAIVRE J., DARDILLAT C., DEBARRE M., THIVEND P., 1979. Re-entrant cannula and automatic sampling for bile study in the preruminant calf. Ann. Rech. vét., 10, 500-502.

NAHRWOLD D. L., GROSSMAN M. I., 1967. Secretion of bile in response to food with and without bile in the intestine. Gastroenterology, 53. 11-17.

SHEFER S., HAUSER S., BEHERSKY 1., MOSBACH E. H., 1969. Feedback regulation of bile acid biosynthesis in the rat. J. Lipid. Res., 10, 646-655.

TALALAY P., 1960. Enzymatic analysis of steroid hormones. Methods biochem. Anal., 8, 119-143.

VAN BELLE H., 1965. In Cholesterol, bile acids and atherosclerosis, 98-99. Noord-Hollandsche Uitgevers Mij., Amsterdam, The Netherlands.

WATTS J., DUNPHY J. E., 1966. The role of the common bile duct in biliary dynamics. Surg. Gynecol. Obstet., 122, 1207-1218.

WEIS E. E., BARTH C. A., 1978. The extracorporeal bile duct : a new model for determination of bile flow and bile composition in the intact rat. J. Lipid Res., 19, 856-862.

WYATT A. P., 1967. The relationship of the sphincter of Oddi to the stomach, duodenum and gallbladder. J. Physiol. (London), 193, 225-243. 